
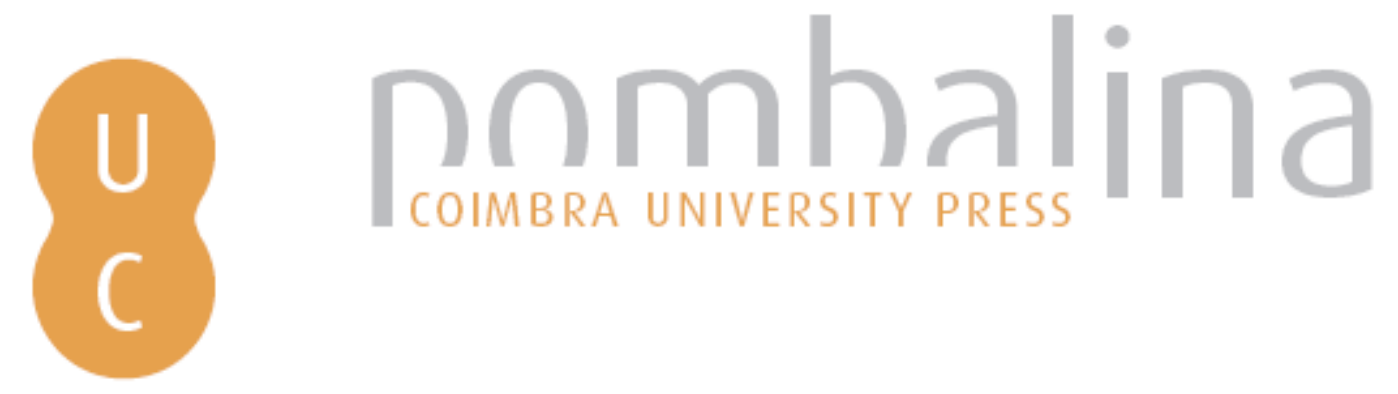

\title{
Urban history and new directions the role of Brinckmann and Laugier for Le Corbusier's urban design theory
}

\author{
Autor(es): $\quad$ Schnoor, Christoph \\ Publicado por: Imprensa da Universidade de Coimbra \\ URL \\ persistente: URI:http://hdl.handle.net/10316.2/41608 \\ DOI: $\quad$ DOI:https://doi.org/10.14195/978-989-26-1338-3_5 \\ Accessed : $\quad$ 26-Apr-2023 14:55:41
}

A navegação consulta e descarregamento dos títulos inseridos nas Bibliotecas Digitais UC Digitalis, UC Pombalina e UC Impactum, pressupõem a aceitação plena e sem reservas dos Termos e Condições de Uso destas Bibliotecas Digitais, disponíveis em https://digitalis.uc.pt/pt-pt/termos.

Conforme exposto nos referidos Termos e Condições de Uso, o descarregamento de títulos de acesso restrito requer uma licença válida de autorização devendo o utilizador aceder ao(s) documento(s) a partir de um endereço de IP da instituição detentora da supramencionada licença.

Ao utilizador é apenas permitido o descarregamento para uso pessoal, pelo que o emprego do(s) título(s) descarregado(s) para outro fim, designadamente comercial, carece de autorização do respetivo autor ou editor da obra.

Na medida em que todas as obras da UC Digitalis se encontram protegidas pelo Código do Direito de Autor e Direitos Conexos e demais legislação aplicável, toda a cópia, parcial ou total, deste documento, nos casos em que é legalmente admitida, deverá conter ou fazer-se acompanhar por este aviso.

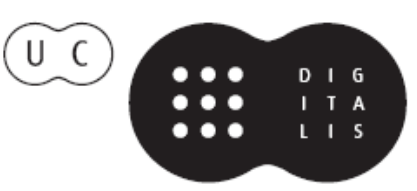


Ivan Zaknic

Arthur Rüegg

David Leatherbarrow

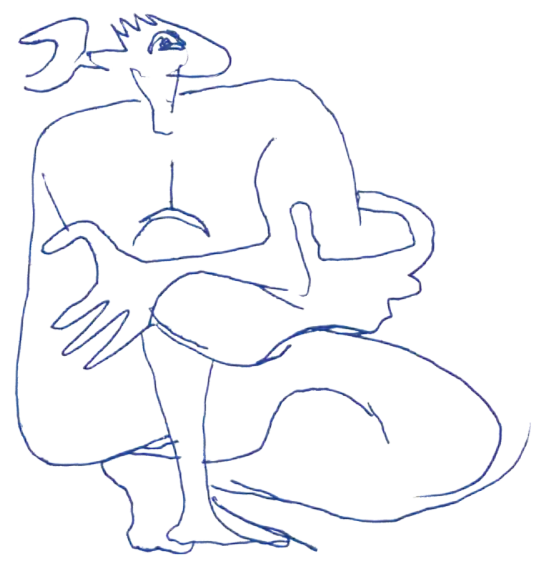

Christoph Schnoor

Francesco Passanti

Johan Linton

Stanislaus von Moos

Maria Candela Suárez

\section{Le Gorbusier}

\section{HISTORY TRADITION}

Edited by

Armando Rabaça 


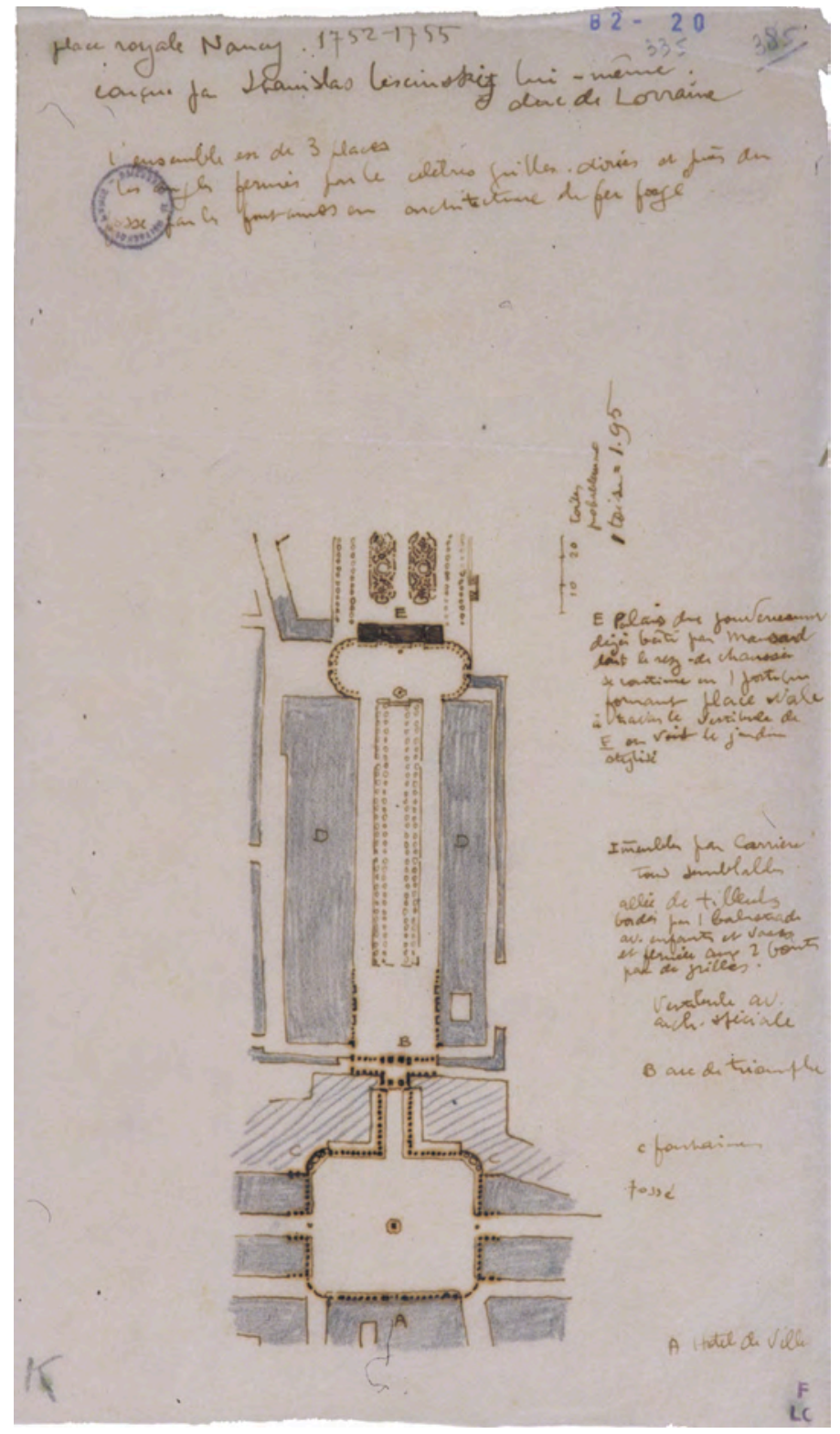

1. Le Corbusier.

Sketch of the Place Royale (Stanislas/Carrière), Nancy, for the manuscript "La construction des villes." 
Ghristoph Schnoor

\title{
Urban History and New Diregtions
}

\author{
The Role of Bringkmann and Laugier
}

for Le Corbusier's Urban Design Theory

\section{INTRODUCTION: \\ Sudden Ghange or Growing Interest in Glassigal Urban Design?}

Le Corbusier readily made use of history to develop his own designs. He was, however, not interested in historical accuracy. He brought together historical models from periods distant and close, moulding them into one architecture that often did not even allow to easily discern these influences. The same is valid for his urban planning. Already in his early book Le Corbusier. Elemente einer Synthese, Stanislaus von Moos made his readers aware of the synthesis of arts in Le Corbusier's work. ${ }^{1}$ And Colin Rowe, noticed an "involvement with a specific rather than ideal Paris . . . an empirical Paris which Le Corbusier so often quoted in his buildings but never in his urbanistic proposals." ${ }^{2}$ Indeed, Le Corbusier was a master in bringing together material from the most diverse sources-be they persons, places or epochs - into a single, well-designed synthesis. Accepting this as one of the most important traits of Le Corbusier's design and writing, this essay, however, does attempt to distinguish between the historical and the contemporary themes that influenced Le Corbusier in his understanding of the city. Focusing on the period between 1910 and 1915, the period of his manuscript "La Construction des villes," leading towards the development of the Ville contemporaine and Urbanisme, this essay investigates the influence of 
urban history on Le Corbusier's urban design thinking. It wishes to show how Le Corbusier - not necessarily consciously - instrumentalised history, both through his studies and observation of the built reality, to aid in preparing his design thinking to conceive new urban forms. ${ }^{3}$

As Harold Allen Brooks and others have demonstrated, Le Corbusier, then still Charles-Edouard Jeanneret, started his architectural development with a strong Ruskinian bias. During his first visit to Florence in 1907, he almost completely ignored any building from the Renaissance and concentrated on medieval architecture instead. During his year (1908-09) in Paris as apprentice of Auguste Perret, he studied and endlessly drew and redrew the Cathedral of Notre Dame instead of appreciating any classical architecture or urban design. Similarly, an Arts-and-Crafts bias applies to his early houses in La Chaux-de-Fonds. ${ }^{4}$

For this reason, historians have for a while now attempted to nominate a point at which Jeanneret's architectural conviction shifted from favouring the medieval and picturesque to the classicist and monumental. Of interest here is the change in his perception of principles of city planning. Antonio Brucculeri and Harold Allen Brooks have set such a point of change in Jeanneret's view of the city at $1915 .{ }^{5}$ Brooks says: "This time he conducted research at the Bibliothèque Nationale in Paris where he became fascinated with classical principles of town planning." ${ }^{\prime 6}$ However I have already shown that one crucial challenge to his belief in picturesque urbanism clearly happened as early as January 1911. While working for Peter Behrens in Neubabelsberg, Jeanneret read Marc-Antoine Laugier's Essai sur l'architecture (in the second edition of 1755) at the Royal Library Unter den Linden in Berlin. ${ }^{7}$ And even that is not the first instance of a change of mind. Francesco Passanti has suggested such a change may have occurred in June 1910 - but without finding a specific event that would have caused this. ${ }^{8}$

The reality may have been a little less black and white. Curiously, an affinity towards the monumental classicism of the French architects and planners of absolutism (Mansart and others) can be observed from the very moment at which Jeanneret developed his notions of a picturesque urbanism, 
i.e. parallel to his reading of Camillo Sitte's Städte-Bau nach seinen künstlerischen Grundsätzen in early 1910. It seems that the picturesque and classicist monumental direction fought for his attention, i.e. that he struggled to develop arguments for either, although it is indeed noticeable that he was quite drawn to the grandeur of classicism, as Francesco Passanti has observed. ${ }^{9}$ So while absorbing, digesting and reformulating Camillo Sitte's theories (Fig. 2), and those of Sitte's followers like Karl Henrici, Paul Schultze-Naumburg, Theodor Fischer and others, he read Albert Erich Brinckmann's Platz und Monument of 1908, and it was through Brinckmann's discussions of French urban squares and monuments that Jeanneret began to grasp the grandeur of the powerful unified French designs of the 18th century. Thus Jeanneret was able to develop a fascination for seeing the city of Paris in a way he had hitherto completely ignored.

\section{Bringimann, Platz und Monument: History of Urban Squares and Monuments}

From April 1910 to March 1911, Jeanneret composed a complex manuscript on questions of urban design. While he had received a travel scholarship by the town of La Chaux-de-Fonds for research into schools and practices in Germany related to the Arts-and-Crafts, he was also asked by his teacher, Charles L'Eplattenier, to write a piece on urban design, to be presented at the Assembly of Swiss communities, scheduled for September 1910 in La Chaux-de-Fonds. Following L'Eplattenier's own interest in art and urban design, this piece was to be based on the theories of Camillo Sitte, as outlined in his 1889 volume, Der Städte-Bau nach seinen künstlerischen Grundsätzen. ${ }^{10}$ Directly after having arrived in Munich in April 1910, Jeanneret began his urban design research, mostly in what is today's State Library, the Royal Library (Bayerische Hof- und Staatsbibliothek), and also in the smaller library of the National Museum. Only interrupted by a summer break that was spent with further writing and editing, back in La Chaux-de-Fonds, 
en $188 \mathrm{~g}$ per liarchitect Viemois Camillo fitte. (1) Cien en un live flein de for, de logione, de

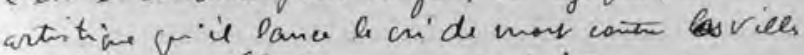
de laideur. Quelpues ameis trimient, de mo: querie et d'indifférence. Pui en Alemagne, des protajomistes $d$ in ars nomban de Gatan as villes, ecriverr de livines, serutent la puestion, four de conférences somettences des

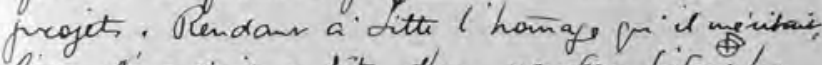

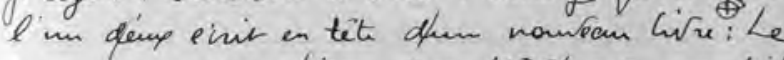
monmens ver litte s'ent éléte' arec son livire, fera commonts son nom au monde de P'avini, come celui du viformaterer de $l_{2}$ conotruction des (vills allemands)s. Cette consiciation des ideces de C. Sitte, novs engagera fenoiensosfois, aucous de ecthe e'tude, Q' ate l'architecte Viemais, afin de domser à de puincifur nowneary $\mathrm{Ch}_{3}$ now, une sanction Solide.

Dyjà is Angleterre, non bear geate philar.

2. Le Corbusier.

Page from the manuscript

"La construction des villes."

Lcdv34 
Jeanneret worked on his bouquin almost without interruption. Having begun as a small piece, this work soon turned into a major undertaking, so much so that at times Jeanneret felt lost in the material. As a result he did not finish anything for the September convention-L'Eplattenier ended up writing an article himself. ${ }^{11}$

Jeanneret studied a multitude of texts on questions of Städtebau in 1910, mostly in Munich. The majority of these texts, written by German-language architects (Sitte, Henrici, Schultze-Naumburg, Hubatschek, Fischer), deal with contemporary questions of the relationship between architecture and the city ${ }^{12}$ Even if they use historical forms as examples, as Sitte and Schultze-Naumburg do, this happens in a manner of theoretical discourse, not historically. Of those texts that Jeanneret studied in great detail, the only one which treats the city and its public spaces from a historical perspective, is Albert Erich Brinckmann's Platz und Monument of 1908. ${ }^{13}$ Brinckmann (18811958), German art historian with a specific interest in Baroque architecture in the Latin countries, was to write many books on urban space. In his approach to the Zeitgebundenheit (era-based quality) of art he was specifically following his mentor and supervisor, art historian Heinrich Wölfflin. Platz und Monument, "Squares and Monuments," investigates the relationship between public urban space and its monuments from the Renaissance to the turn of the 20th century. As Jochen Meyer reminds us, "A particular achievement of Brinckmann is the reconsideration of urban planning achievements of the Renaissance, Baroque and Classicism." "14 For Brinckmann, there was no question that the building of a city was art, calling one of his presentations "The City as Work of Art (Die Stadt als Kunstwerk)." ${ }^{15}$ This should be appreciated accordingly: here was a book which differed from the contemporary architects' assessments of urban spaces. Brinckmann was breaking new ground with an art historical investigation of Städtebau. When Jeanneret studied Brinckmann's volume, it had been published just two years earlier. And it is no small thing that Jeanneret found this source useful for him-particularly in guiding him toward the French urban designs of the Baroque and Classicist periods. 
It seems that Jeanneret began to read Brinckmann in May 1910 - this is the date to which the earliest excerpts can be dated. More than twenty pages of Jeanneret's manuscript directly paraphrase Brinckmann or are related to his historical accounts of Italian and French urban spaces and the respective placement of monuments. ${ }^{16}$ But more than that, he would find in Brinckmann's book judgements on the general appearance of a city. Thus, in a phrase that strongly resembles Laugier's famous formulation of the order in the detail and the variety, even tumult in the whole, Brinckmann claims that each effect, no matter whether of a building or urban intervention, is relative to the context:

Nothing is achieved by simply setting something down in a city or building something up within it; everything depends on how. The various beautiful elements result in the city's overall beauty; the well-formulated harmonious details will develop into a great, rich manifoldness in overall impression [emphasis by author]. ${ }^{17}$

This paragraph and others from Platz und Monument did not go unnoticed with Jeanneret at all. He developed his own first theory of well-designed public squares almost equally from Brinckmann's as well as from Sitte's theories. It is fascinating to see how close Sitte and Brinckmann are in much of their argumentation, and where they differ. Both strongly advocate a sense of spatial enclosure in public urban spaces. However, Brinckmann postulates a sense of spatial unity more strongly than Sitte. While for Sitte, enclosure was possible with varying façade treatment, ${ }^{18}$ Brinckmann was closer to what Walter Curd Behrendt would argue for in his dissertation a few years later: Die einheitliche Blockfront als Raumelement im Stadtbau - the unified enclosed street front in urban design. ${ }^{19}$

In one of his cahiers (Fig. 3), Jeanneret sketches the end of his chapter Des moyens possibles: taking up Brinckmann's dictum that the city is to be understood as architectural unity, starting from the rooms, to single buildings, to groups of building, seeing them as "material of Stadtbaukunst,"20 Jeanneret 


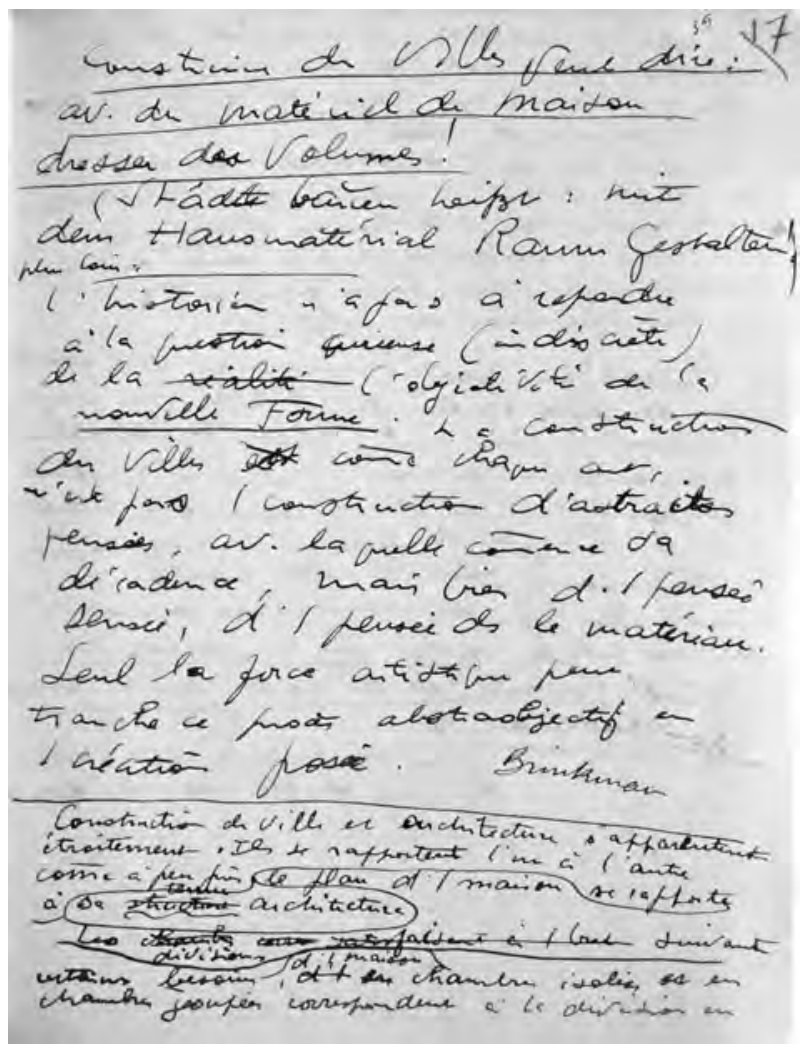

3. Le Corbusier.

Page from the manuscript "La construction des villes." Lcdv448 
calls for a sense of space to guide urban design.

Now a building, a city, a room, these are all merely the applications of a taste for beautiful volume. It is this volume which we must teach the crowds to understand, and the architects to create. They will make a room, and then a house; and then a street, then a square, with the right volume, with beautiful volume. Let us conclude with what Mr. Brinckmann summarises perfectly [in] his book. To construct cities is to shape spaces using buildings as material! (Städte bauen heißt: mit dem Hausmaterial Raum gestalten!). ${ }^{21}$

For Jeanneret, Sitte and Brinckmann become the starting point of, if one will, two contradicting principles for placing monuments on a public square. Jeanneret chooses to present these principles in such a way that today's reader is able to perceive a struggle within his understanding of public space: firstly, he expands on the notion of the "dead point", as explained by Camillo Sitte. This is the placement of monuments in a corner or other part of the square undisturbed by traffic.

Why do so many old squares, which have remained sheltered from planning devastation, offer strange undulations in their surfaces? These are grooves dug little by little by carriages passing repeatedly along the same track, making slightly raised areas which have, as if by design, become pedestals seemingly designed for siting monuments. It is precisely at these points that one should seek antique fountains, wells, wayside shrines, big trees and their stone benches, the quiet evening meeting places. Sitte claims to have observed that, in winter, children in villages always instinctively build their snowmen at the 'dead point.' Here then is the public square divided into areas propitious for placing monuments. ${ }^{22}$

However, Jeanneret also recognizes that there are situations in which this rule might not apply. Turning to the French models of the symmetrically shaped squares, in particular designed for Louis XIV and XV, he follows 
Brinckmann's examples. These absolutist kings generally had their sculpture placed in the geometric centre of the square. For his analysis of these urban situations, Jeanneret relies on Brinckmann but does not copy him, rather summarizes and discusses in a more general fashion..$^{23}$ Although Jeanneret shows fascination for the centralized square, only very few of the many sketches and hard-line drawings that he crafted for the manuscript in 1910 do represent French centralized squares. At least the Place des Victoires in Paris and the Place Royale (Carrière/Stanislas) in Nancy figure in his body of drawings, both copied meticulously from Brinckmann's Platz und Monument (Fig. 1). ${ }^{24}$ The latter is important here: Jeanneret would visit Nancy in 1914 and sketch, on site, its various architectural and spatial characteristics. ${ }^{25}$

But whereas Brinckmann's aim is to demonstrate historical differences between epochs and cultures, and thus is historically as precise as possible, Jeanneret seems more interested in the principle than the historical detail. It could be said that he is closer to Camillo Sitte in this. And for our discussion it is crucial to see that history and historical events are being used by Jeanneret at this point to argue for a grander aim, which I believe is the notion of urban space as a contained entity between the mass of buildings.

Towards the end of Platz und Monument, Brinckmann attempts to distance himself from the ever-present Sitte, by criticizing his leaning toward the curved and irregular elements of city planning: "A street is not made beautiful by bending the façades of apartment blocks like playing cards." ${ }^{26}$ And Brinckmann weighs the curved against the straight street: "A desire to open up the view gave rise to the straight, tidy street. As much as the meandering, irregular street ... on hilly ground ... is justified aesthetically as a contrast to the straight, open street, it cannot create a perfectly monumental situation.”27 Spurred by Brinckmann's view, Jeanneret comments on the grandeur and beauty of the long and straight road, pointing out that the "straight line in nature is the noble line par excellence; but of course it is also the rarest," and highlighting some of the grand roads in Paris and Berlin:

A certain slope or dip will benefit this street, and it will always be enclosed at 


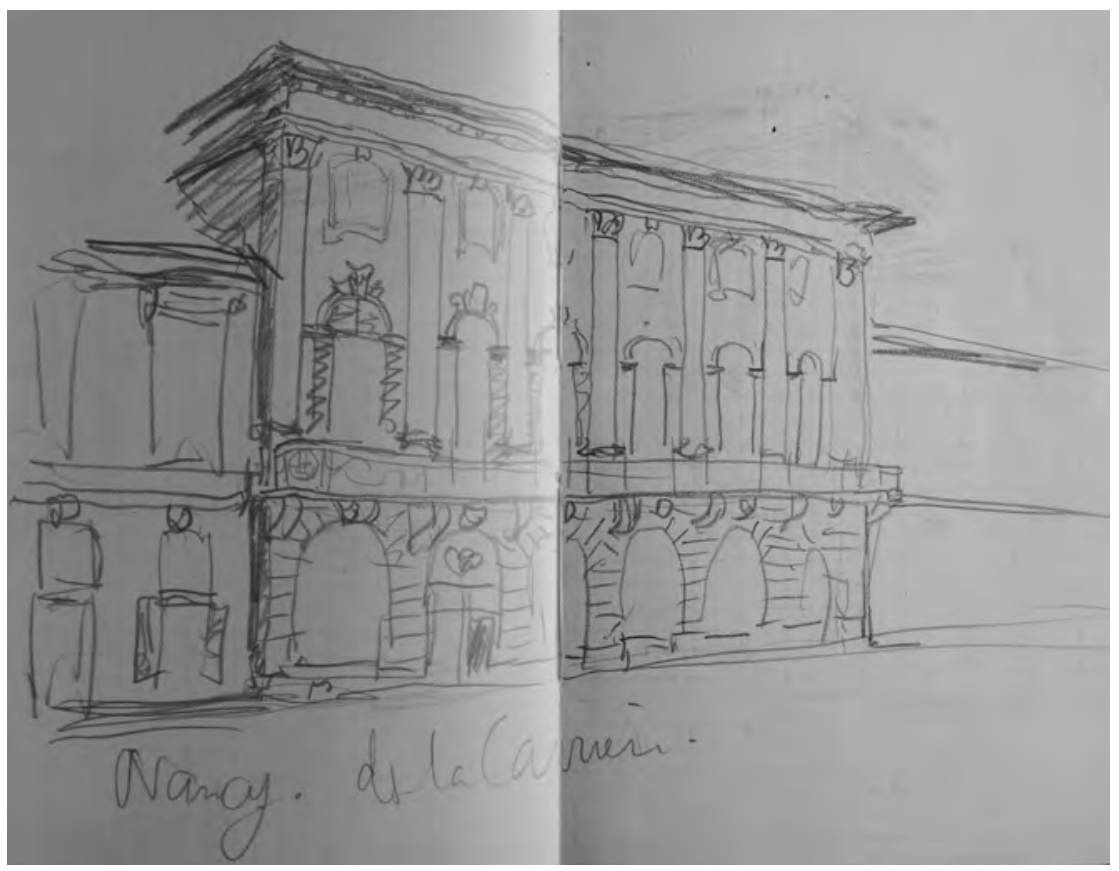

4. Le Corbusier.

Sketch of the Place de la Carrière, Nancy.

Carnet 1914, 12, 13. 
its upper end by a monument to glory. Skilful orientation will make the street even more magical. Such is the avenue des Champs-Elysées in Paris, crowned with the immense Arc de Triomphe, behind which the sun sets gloriously. So too in Berlin, the 'effect' of the Siegesallee at the end of which the Siegessäule stands drowning in the crimson of the setting sun, almost mirrored in the tarmacadam polished by automobiles. - Bismarckstrasse in Charlottenburg with its enormous dimensions follows a fixed direction for miles, almost the only straight line through districts which are and will be designed according to the new procedures. ${ }^{29}$

Here, in Brinckmann's criticism of the curved street, lies the intellectual starting point of Jeanneret's early criticism of Sitte and of exaggerated picturesque planning. Summarizing parts of his readings, he observes this tension between Sitte and Brinckmann, first saying: "Germany having accomplished, and still accomplishing, reform is already at the stage of reaction!" - only to add that, "[i]n fact, some blundering disciples of C. Sitte, going beyond his theoretical position, would if nobody stopped them, almost have revived that mediaeval era which this eclectic Viennese so brilliantly restored to favour in his book." 30

So Jeanneret very clearly sees the danger of overrating the picturesque. He also points out that some writers are aware of this risk, but warns at the same time that such fine-tuned criticism could be too differentiated in a discussion that is usually conducted with the broad brush:

Relishing the reforms accomplished, but already wary of all-too-hasty satisfaction which would invoke a crippling status quo, they identify certain unhealthy tendencies; but by denouncing these - as Mr. Brinckmann doeswithout additional deliberations, they risk confusing the uninitiated reader, the simple inattentive onlooker who does not know the heart of the matter. ${ }^{31}$

In summary: both Sitte and Brinckmann put their emphasis on the sense of enclosure of public spaces. While Brinckmann disagrees with some of 
Sitte's positions (the picturesque vs. the monumental), Jeanneret is fully aware of these subtleties.

However, it seems that many of the remarks on Parisian (and other French) urban situations which Jeanneret received from Brinckmann, did not develop their impact on him in mid-1910. There may have been an incubation period of a few years for these insights to be fully realized, until 1914, when Jeanneret was passing through Nancy, and 1915, when back in Paris, he visited these urban ensembles, thereby newly calibrating their importance for his understanding of the city. Only in 1914/15 - with eyes that now do see? - he recorded, in notebooks that had hitherto been thought lost, his impressions of both the Place de la Carrière in Nancy, and of the squares and places of Paris.

\section{1: Laugier Through Bringkmann}

But to return to Jeanneret's reading in 1910: it is by studying Brinckmann that he takes notice of Marc-Antoine Laugier's writings. In May 1910 he notes Laugier's dictum on regularity and chaos in the city as quoted, in French, in Brinckmann's Platz und Monument: "Laugier disait: il faut de la régularité et de la bizarrerie, des rapports et des oppositions, des accidens qui varient le tableau; un gd ordre dans les détails, de la confusion, du fracas, du tumulte dans l'ensemble." ("Laugier said: There must be regularity and whimsy, relationships and oppositions, chance elements that lend variety to the tableau, precise order in the details, and confusion, chaos and tumult in the whole.") ${ }^{32}$ This is the crucial link: Jeanneret is introduced to Laugier by Brinckmann through the latter's investigation of French urban planning of the 18th century. As surprising as it may seem that Jeanneret "needed" a German historian to be made aware of French urban history, this may have been a pattern around 1910, where German architects and historians (re)discovered French urban design from the time of absolutism and introduced this view to the German readers. And it is this quote that, now 
calling himself Le Corbusier, he uses in Urbanisme to discuss the question of order and variety in the city:

Voici, formulée, une conclusion idéale, précise. Déjà sous Louis XIV, l’abbé

Laugier l'avait énoncé:

1. Du chaos, du tumulte dans l'ensemble. (C'est-à-dire une composition riche d'éléments contrapuntées, fugue, symphonie.)

2. De l'uniformité dans le détail. (C'est-à-dire de la retenue, de la décence, de 'l'alignement' dans le détail. ${ }^{33}$

However, in 1910/11, Jeanneret left Laugier's Observations sur l'architecture, from which this quote stems, largely unnoticed, even if they could have given him a wider insight into Laugier's urban ideas. Instead, he eagerly studied Laugier's Essai sur l'architecture in its second edition of 1755 (1st 1753), excerpting from and commenting on the Essai a whole forty-six pages of his last cahier (Fig. 5).$^{34}$ But instead of delving into Laugier's architectural theory, Jeanneret devoted most of his attention to Laugier's criticism of Paris and his suggestions for an urban redevelopment of France's capital.

At the turn of the year 1911, Jeanneret lived in Neubabelsberg, on the outskirts of Berlin, of which he said: "I am not convinced by Berlin, and when one leaves the immense avenues, there is only disgust, and horror," ${ }^{35}$ and which he found dreadful in the monotony of its "rues corridors." On the other hand, he adored the grand gesture of the Siegesallee towards the Brandenburg Gate. And while he worked, under Behrens, on neo-classicist buildings, Jeanneret began reading Abbé Laugier's Essai; this is between mid-January and the 12th of March, $1911 .{ }^{36}$ As much as it is not surprising that Jeanneret would study Laugier at some stage, the specific point in time is somewhat unexpected. One wonders what might have prompted him to study the Essai, and just that. This is particularly so because it seems from the dates in the notebook that Jeanneret would have travelled to the Königliche Bibliothek, the Royal Library at Unter den Linden, on weekdays (e.g. Thu, 26 January). Therefore: was studying the Essai something that had 


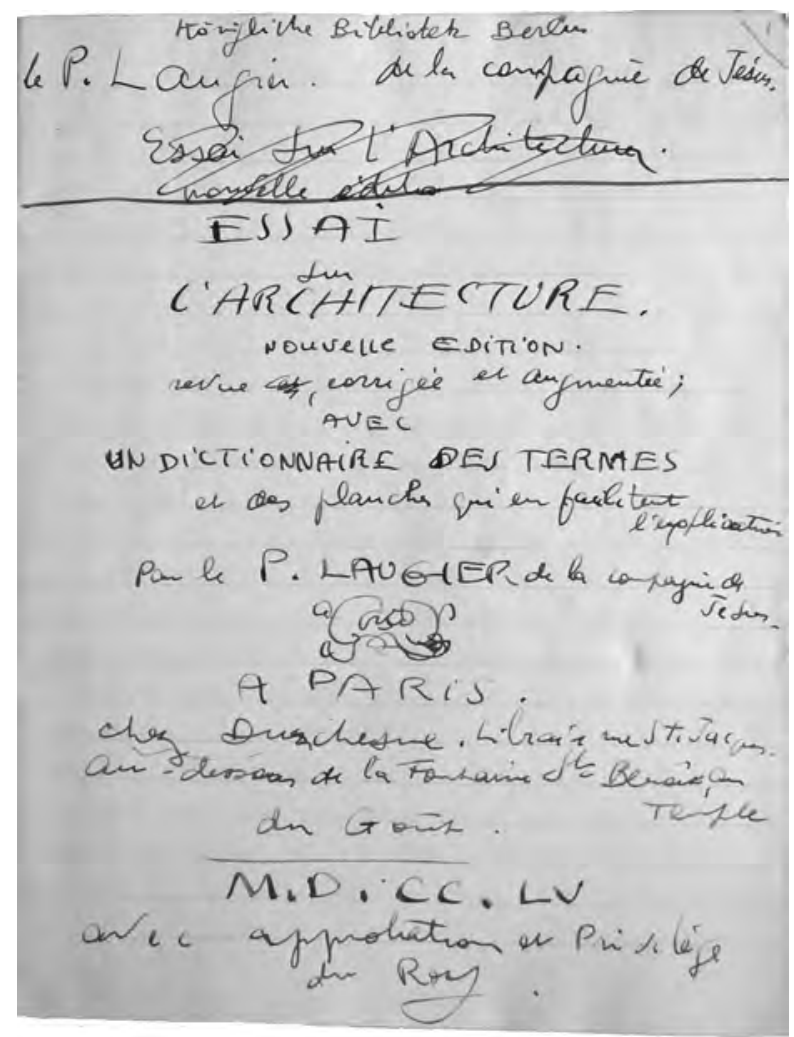

5. Le Corbusier.

Page from the manuscript

"La construction des villes."

Lcdv 475 
been requested by or simply supported through Behrens's practice? It is quite clear that Behrens's office was one of the best places at the time to be close to the artistic and intellectual debate on modern architecture. Hendrik Petrus Berlage's book Grundlagen und Entwicklung der Architektur ${ }^{37}$ was available in the office, as well as August Thiersch's proportional studies ${ }^{38}$ (which led, amongst other sources, to Le Corbusier's tracés régulateurs) — and Wright's Wasmuth Portfolio ${ }^{39}$ In short: through the distance of a century it looks as if there was hardly a better place for Jeanneret to absorb the current architectural debate, which included theories developed through history.

\section{Laugier as Starting Point of a New Perspegtive on the Gity}

Laugier's Essai could have such an impact on Jeanneret because Laugier proposed to abolish the old, winding streets of historical Paris and to design something larger, grander, instead. It might have been as if Laugier had directly criticized Camillo Sitte's theories and everything that had to do with the topic of irregularity. Or was it quite like that?

On over 40 pages of this cahier, Jeanneret copied passages of Laugier's Essai, 25 of which are devoted to questions of urban design, covering topics such as entries of a town, the street layout, and gardens, including the park of Versailles. Laugier's core argument on these pages is that Paris needs to be redesigned, and that it requires a sense of monumental grandeur, with wide roads, magnificent entries with triumphal arches. Laugier also presents the idea - with Jeanneret noting this - that the city needs to be conceived as a park, and, in that context, that a good balance of order, symmetry and variety need to be applied: "Il faut regarder une ville comme une forêt." ${ }^{40}$ Laugier says: "One must look at a town as a forest. The streets of the one are the roads of the other; both must be cut through in the same way. The essential beauty of a park consists in the great number of roads, their width and their alignment." And he continues to describe how this park should be designed with "at one and the same time order and fantasy, symmetry 
and variety," culminating in: "The more variety, abundance, contrast and even disorder in this composition, the greater will be the piquant and delightful beauty of the park." ${ }^{42}$ In this manner, Laugier's comments on the park become directly transferable to aid Jeanneret's understanding of the intended unity of a city's design. Having excerpted all these ideas, Jeanneret finishes the cahier with a long and very clear rejection of the picturesque:

My impression of this book: ... His ideas about urban design are perfect for his era, and for art ... Always striving for the grand style, which is superior to the surprises and entertainment of the pictorial ... In the present day, when a reaction can be detected against the outdated principles of the mediaeval pictorial style developed by Sitte, Laugier speaks with uncommon force because he is of an era which has already tried and tested the grand style and which, having reached saturation point, but also strengthened by this extraordinary development, has turned towards charm and grace. We are emerging from our spinelessness, we have allowed ourselves to be exploited by a childish crisis of romanticism, and are yearning for a style which, as an expression of the growing wisdom of our philosophy and science, of the generosity of our social aspirations, will take shape to express this in adequate terms i.e. more as abstract beauty than petty materialism, one which tends towards greatness, which is a sign of the masses marching in unison and overthrowing the pictorial that marks out an individualism which is impoverished by its narrowness. ${ }^{43}$

Those pages by Laugier, describing the monumental entries to a city, the intersections in the form of patte d'oie, triumphal arches and similar, practically form the base of Baron Haussmann's percement and redesign of Paris, exactly 100 years after Laugier had written them. And it is difficult not to think of Le Corbusier's 1920s urban designs while reading these passages since they sound like a direct preparation of the Ville contemporaine. With this in mind, one can draw the line from Laugier via Haussmann to Le Corbusier in the perception of the role that monumental order plays or should play for Paris. 
What kind of images, however, Jeanneret might have had in front of his inner eye in 1911 when reading these lines is impossible to know, of course. But even if a mostly futile attempt, there may be some value in asking what reference streets and buildings there might have been that could have embodied for Jeanneret in early 1911 what Laugier had written about 150 years earlier. This might be the University in Munich, in fact the whole Ludwigstraße - with the Royal Library where Jeanneret spent many days in 1910 studying literature on Städtebau; the long and straight Bismarckstraße in Berlin and possibly even Unter den Linden; plus designs Jeanneret saw at the Städtebau-Ausstellung in Berlin, June 1910.

\section{William Ritter and \\ the Question of a Fungtional or Aesthetic Gity}

Jeanneret's Voyage d'Orient in 1911 interrupted further attempts at pursuing his studies of urban questions. Having learnt this much on urban design, walking through Istanbul and Rome however triggered further ideas. The volume Le Corbusier before Le Corbusier speaks of these experiences. ${ }^{44}$ These have a lot to do with the Swiss writer and art critic William Ritter. During the latter part of the year 1910, Ritter became first a friend, later a mentor for the young Charles-Edouard Jeanneret (Fig. 6). Ritter influenced Jeanneret intellectually, even became a fatherly support person with whom Jeanneret could communicate about feelings of essential self-doubt. Elsewhere, I have called him a therapist for Jeanneret; this is valid at least for the early years of their mutual friendship. ${ }^{45}$ Ritter's influence, however, also manifested itself in a re-orientation of Jeanneret's architectural interests, at least temporarily, away from "La Construction des villes" and towards the Voyage d'Orient. Having encouraged him to see the vernacular cultures of the Balkan, Ritter strongly advocated that Jeanneret should publish his journals of this voyage. While he was of the opinion that Jeanneret was dealing with unnecessary, maybe even irrelevant questions of an aesthetic of the city, he would have 
Urban History and New Diregtions

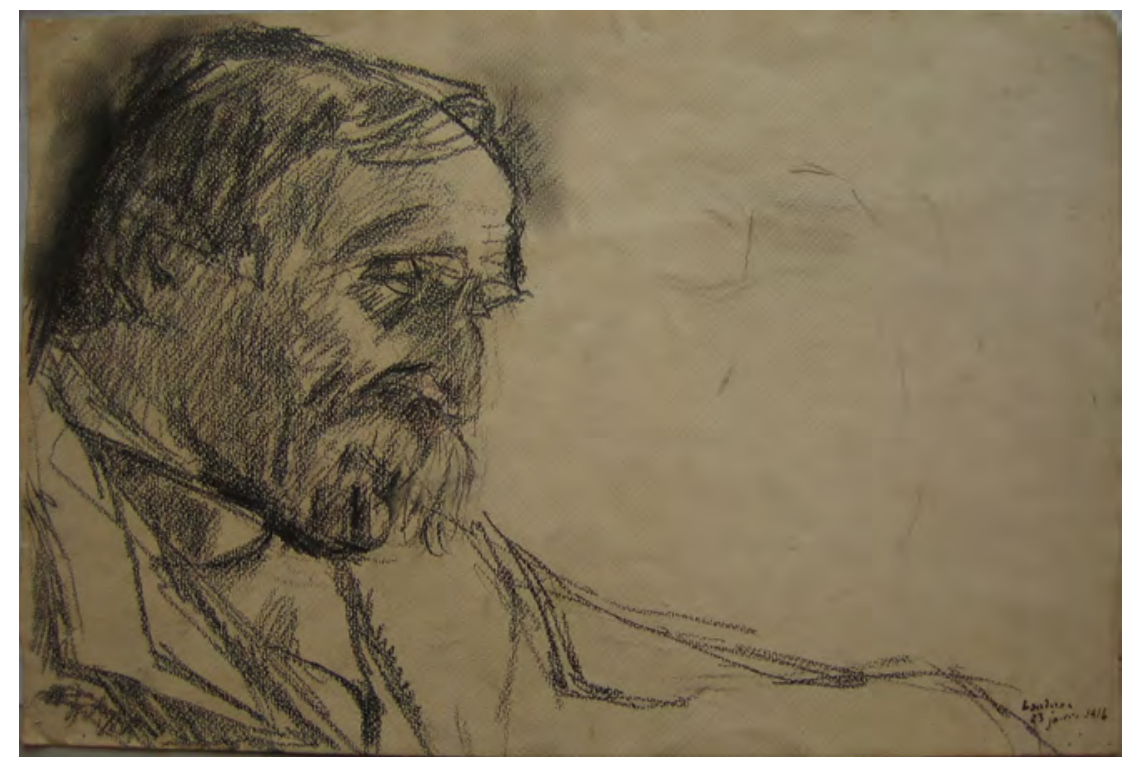

6. Le Corbusier.

Portrait of William Ritter, 1916. 
steered Jeanneret towards seeing the city through its functional requirements. Ritter wished Jeanneret to set his own priorities: "Make what is beautiful for yourself, as it pleases you," but equally "make beautiful things for your people, things it needs; and it will be for the people, not you, to decide what it needs." ${ }^{46}$ In a letter of September 1911, Ritter used pigs as an example to make his point, in his inimitable strong and colourful language:

You may call it a paradox, but just reflect on this for a minute: it is the stomach that digests, and food is made for the stomach. Imagine food revolting against the stomach: food decides one fine day that its main purpose is to be beautiful. From then on, the stomach can no longer tolerate it and says 'I don't give a d. about your beauty; beauty to me is something I can digest.' The problem is not to be theoretically beautiful but to be digestibly beautiful. ${ }^{47}$

Ritter concludes his letter with the following observation:

If one casts pearls before swine, it is not the swine who are stupid. I am amazed that nobody appears to have realised this before ... For a pig, the aim is to be a very pretty piglet. Your job is to help it achieve that and not to transform it into a gazelle or a guinea fowl. Take a look at the Acropolis, it will tell you whether or not I'm talking nonsense, and whether I'm just a doddering old b[ugger]. ${ }^{48}$

Ritter appears enormously far-sighted in these comments: it is almost as if he anticipated the post-modern debate on modernist architecture. This highly useful criticism allows us to look ahead towards the Ville contemporaine which is, indeed, a much stronger aesthetic statement than it is the "tool" that Le Corbusier purported it to be. ${ }^{49}$ In 1911, however, Ritter's judgement is - at least partially - unfair since Jeanneret had indeed incorporated functional questions into his treatise "La Construction des villes," or rather: not only had he incorporated them but often argued in functional terms, while always in conjunction with questions of beauty, and if in doubt, would have given aesthetic considerations priority. ${ }^{50}$ But his early "treatise" is not 
just City planning according to artistic principles: what Jeanneret assembled is a well-considered argument for a well-functioning, aesthetically considered urban design that takes into account the perception of the city's user - a point that, as modernist architect, he would almost fully neglect, and that needed a Gordon Gullen, or a Kevin Lynch to be brought back into the debate. $^{51}$

Thus, "La Construction des villes" was not pursued further by Jeanneret between 1911 and 1914; it seems that without Ritter's support, and at a time where Jeanneret's bond with L'Eplattenier was waning, the question of aesthetics of the city had little chance. But in 1914 interest was rekindled. Is it the commission by Arnold Beck that instigated this? A trip to the Werkbund exhibition in Cologne via Nancy, and then in 1915 the visit of the Bibliothèque Nationale in Paris helped Jeanneret to re-direct his interest in urban questions. History — in built and written form — spurred his fascination and helped him to envision the new city. ${ }^{52}$

\section{4: Gité-jardin in La Chaux-de-Fonds and Plage de la Garrière, Nangy}

In 1914, Jeanneret's intellectual investigation of the urban realm and its architecture was extended in two opposite directions: firstly, he was asked to design a garden-city settlement in La Chaux-de-Fonds, for investor Arnold Beck, a project that was not realised..$^{53}$ Jeanneret drew a plan and perspective for the Cité-jardin aux Crêtets that directly refers to, even copies Georg Metzendorf's housing estate for workers of the Krupp factories in Essen-Margarethenhöhe of 1909. ${ }^{54}$ Jeanneret's design draws on Heimatschutz motifs and picturesque layout principles organising rows of houses following the contour lines of the terrain and featuring a gate building which clearly demarcates the entry to the housing estate in a manner close to other architects interested in an Arts-and-Crafts vernacular - one might see Voysey or Tessenow in these houses (Fig. 7). This design demonstrates how two 
Christoph SGhnoor

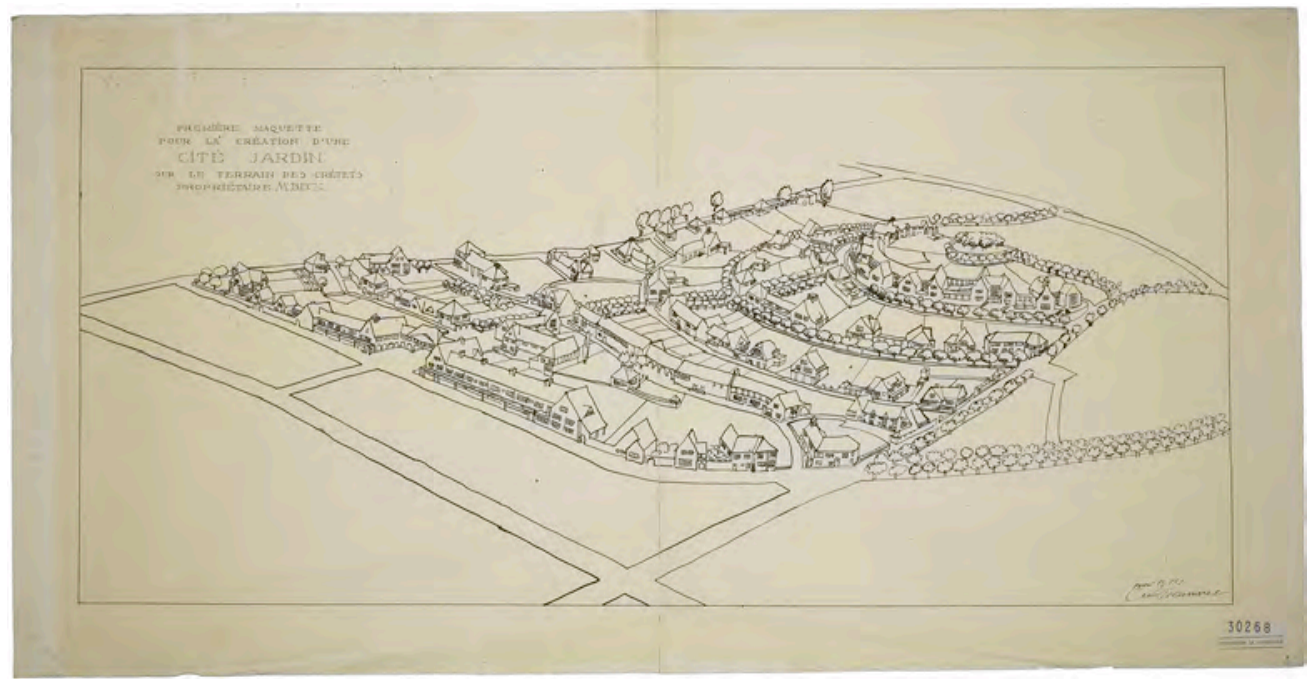

7. Le Corbusier.

Cité-jardin aux Crêtets, 1914. 
notions of the urban run parallel in Jeanneret's mind: here the picturesque (for garden cities), and there the monumental, even classicist notion of a Laugier or Haussmann.

In the same year, Jeanneret travelled to the Werkbund exhibition in Cologne (15 May to 8 August), visiting Nancy on the way. Leaving La Chaux-de-Fonds on the 27th of June, he spent the following day in Nancy. There, he recorded his observations of the architecture in his travel carnet. ${ }^{55}$ He sketches - quickly, but with enough precision - the characteristics of the ensemble of the Place Royale, both as seen by the visitor and in plan, and details of the columns, façades etc. over eleven pages, adding notes with comments. Jeanneret very carefully documents his impressions of the architectural qualities of the Place de la Carrière, making notes on the ensemble of small houses that together form the space: "what makes the shape of the Carrière are the small houses," ${ }^{, 56}$ describing their materiality and detail (Figs. 8, 4). He continues by describing and judging - often in one flow - the sweeping curve of the hemicycle and its ionic order. He further notes how two columns jointly sit on an oval base, etc. - not the slightest sign of a tiredness with classical architecture is noticeable through these notes. And he speaks of the square as an example of "sagesse," the wisdom that is "imposed" on the citizen..$^{57}$

With his visit of Cologne in early July, Jeanneret would have just caught the exhibition a month before it was closed due to the beginning of the war. ${ }^{58}$ Bruno Taut's glass pavilion only receives half a page of sketches and annotations, however Gropius' exhibition hall is studied carefully (Fig. 9), with Jeanneret even noting to ask Gropius how some elements were made and being impressed with the round glass stairs, comparing the section of the hall to Behrens's design for the German embassy in St. Petersburg. ${ }^{59}$ Still, one knows little about the importance Jeanneret ascribed to his urban design preoccupations during 1914. 


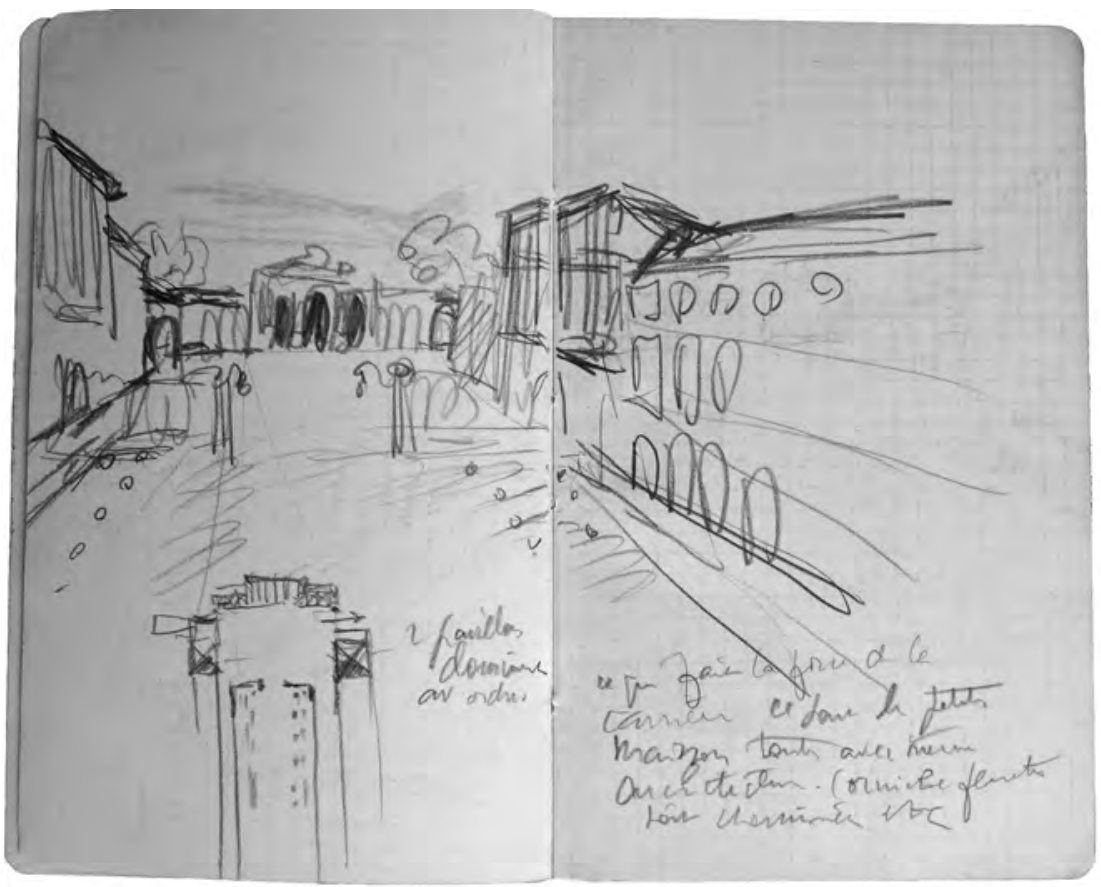

8. Le Corbusier.

Sketch of the Place de la Carrière, Nancy. Carnet 1914, 4, 5. 
Urban History and New Diregtions

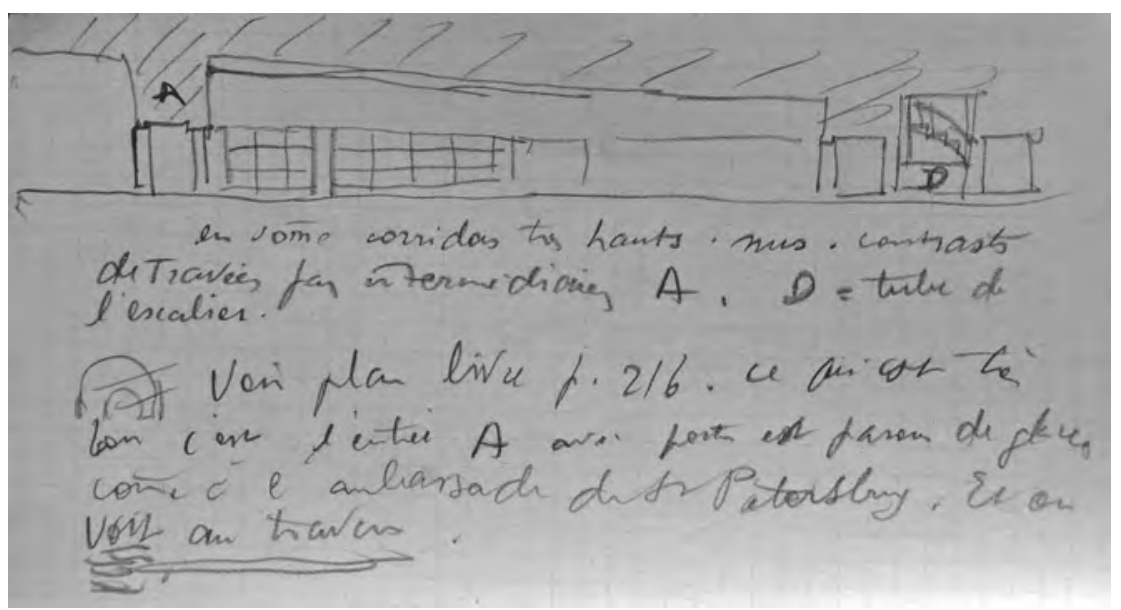

9. Le Corbusier.

Walter Gropius, Pavilion at the

Werkbund exhibition in Cologne, 1914.

Carnet 1914, 52.

Private archive, Switzerland. 


\section{5: Before the Departure to Paris}

A Regonsideration of the 1910 Writing

In 1915, Jeanneret developed the idea to pick up his semi-abandoned manuscript "La Construction des villes" and to bring it to publication. In his letter to Auguste Perret of 30 June, 1915, Jeanneret writes:

I will come to Paris soon, for the publication of a book which I have written about urban design and expansion plans etc.. A strong work and very balanced, but with a narrow focus and written tortuously. I will completely rework it. I'm coming to Paris to find a publisher. I thought to myself that this would be the right opportunity to bring back the study from obscurity and that this modest effort could prove very useful at present, as rules on this matter are being discussed. ${ }^{60}$

Before Jeanneret travelled to Paris in late July, he revisited the unfinished manuscript and wrote a whole survey of his work to date, containing 18 pages of an enormously detailed summary of the content. Surprisingly, despite all the contradicting stimulations of the four interjacent years, not much had changed to his 1910 version! If we follow Passanti's suggestion in his 2002 essay (and many others), Jeanneret's fundamental attitude towards the question of picturesque vs. classicism would have changed radically, and we would expect the arguments for a picturesque arrangement of elements of the city to have been thrown out. But despite his reading of Laugier's Essai in early 1911, he had not yet touched on the content of his treatise very much to reflect this reading. In his "Avertissement," the introduction, a few changes are nevertheless looming. Therefore it might be worthwhile quoting it in full here (even if it is in abbreviated language):

\section{FOREWORD}

\{More editing to do\} This book would have remained unpublished as thesis still disappointing. Complexity, and disorder in current taste. 
And in the past, if everything had been done, so many examples that seem to flout the rules we believed to have discerned.

One thing made me determined to create it: the rebuilding of the towns and cities in the north and Flanders. One thing encouraged me: seeing that in France this is being addressed \{spaces\}; knowing that there are as yet no works popularising this subject.

Efforts such as at the Expo in Lyon (city building department). Complex theme, because difficult to follow a path that is very objective: at every turn, ideas are put forward, overturned, opposed etc. Questions abound: of a practical nature, a business, moral, psycho[logical], philosophical, social \{political\} nature, etc. My aim is not to propose a solution for whatever question. Instead, by studying a bit of everything, everywhere, from all periods and all places, [I aim] to bring the question back to life. To attract people interested in it, with skills in it, excite interest and discussion.

To bring it to life: in short, to put that question which is believed to be the exclusive preserve of technicians before the public at large - who are the judges of it because they are the intended recipients of the technicians' work, the public who command it and determine the technicians' tasks. To create a body of opinion, from which action [will emerge] on legislators, and on [without?] technicians. To create demand, as in commerce (a city has the architecture it deserves. W.R. ${ }^{61}$ )

The type of argument: the past/the present/the future

The past studies the causes and results (explain the multiple processes, the contradictions due to different tastes, customs, era). I point them out to enable decision making.

The present: what is being done in America, Britain, Germany, Switzerland. Advances above all where ugliness was unbearable. Therefore less pressing [powerful?] in France.

Future what one could do.

Study of different factors: Materials: cost/sculptural/practical/hygienic. ${ }^{62}$ 
So Jeanneret explains why he has not published the treatise yet: the hypothesis was disappointing, underwhelming - but does he refer to his own research or to what he got out of it? But now as he sees an opportunity, even a need for the rebuilding of the cities in Flanders and since France officially deals with this problem, he feels that his treatise might remedy the lack of a popularizing work on this topic. He sees the past as a field of study of the causes and results of developments. And Jeanneret takes into account that conditions change - this is Brinckmann's historical approach: "The downfall of XIX-century architecture is that architects were unable to feel space and spatial effect ... Even if they succeeded in copying from history in detail, they fail to realise that the changing architectural form merely expresses a changing sense of space." ${ }^{63}$ Jeanneret had noted this to himself back in 1910: "noter que le Raumgefühl change avec les époques (note that the sense of space changes with the eras)." ${ }^{\prime 64}$

\section{5 in Paris: Establishing a New View on the Gity}

Jeanneret left for Paris on the last days of July 1915 where he delved into library studies in the Bibliothèque Nationale. The intended stay of three weeks was prolonged to seven. ${ }^{65}$ He devoted part of his work to two major tomes: Topographie de France by Gabrielle Pérelle, dated 1753/66 and Monumens érigés en France à la gloire de Louis XV by Pierre Patte, dated 1765, which may have served as inspiration for his radical treatment of central Paris in his 1925 Plan Voisin. ${ }^{66}$ Antonio Brucculeri traces Jeanneret's criticism of the historically disorderly state of Paris back to Pérelle; however, as shown above, Jeanneret had already absorbed such a critique through Laugier's Essai in 1911. Jeanneret's bibliography from his stay in Paris covers 80 works on architecture and urban design throughout the centuries, he drew new sketches as illustrations and copied extracts in tiny handwriting, to produce a full hundred pages of raw text on urban design ${ }^{67}$ Jeanneret's excerpts from the Bibliothèque Nationale have yet to be fully transcribed.$^{68}$ Nevertheless, 
it can be established that in 1915 Jeanneret built on his 1910 research: a considerable proportion of the 1910 bibliography is listed again, naturally including in particular those books he had not yet tackled, or not in any detail. This category includes Brinckmann's Spätmittelalterliche Stadtanlagen in Südfrankreich, Charles Buls' Esthétique des villes, Joseph Stübben's Der Städtebau, and Raymond Unwin's Town planning in practice, then Roland Fréart's Parallèle de l'architecture antique av.[ec] la moderne and Laugier's Essai sur l'architecture, from which Jeanneret had already quoted, Laugier's Observations sur l'architecture and Pierre Patte's Mémoire sur les objets les plus importans de l'architecture. ${ }^{69}$ Additionally, works of classical architectural theory from antiquity through Renaissance to Classicism show up in Jeanneret's bibliography: Vitruvius, Alberti and Palladio, alongside French theoreticians such as Blondel, Briseux, de l'Orme and Perrault, plus contemporary essays and works on social and technical questions in urban design. Such a comprehensive bibliography suggests that Jeanneret felt a need to compensate for some intellectual shortcomingperhaps piqued by his discussions with Ritter? Like the excerpts, the sketches Jeanneret made in the Bibliothèque Nationale still await in-depth analysis. These sketches cover French urban design of the 17th and 18th centuries as well as European and Far Eastern urban design subjects spanning all eras.

Marie-Jeanne Dumont notes that "Evidently, Le Corbusier knew German architecture and journals better than French." ${ }^{.70}$ And indeed, this shows where Jeanneret, in a letter to Perret, lists several German publications (on works by Peter Behrens, Theodor Fischer, the Werkbund, etc.) which he suggests to supply Perret with, demonstrating how well-versed he was in the Werkbund debate and general architectural progress in Germany at the time. ${ }^{71}$ At the same time, Jeanneret would have felt a lack of knowledge concerning French architectural culture, a gap of which his reading of Brinckmann and Laugier would have only made him more aware. The journey to Paris 1915 and into the thicket of the Bibliothèque Nationale meant a slowly growing understanding of French culture for Jeanneret, the culture he would claim more and more as his own, despite having been raised in between three cultures, that of French-speaking Switzerland, France and Germany. 


\section{Paris Atmospherically}

At the same time, Jeanneret wandered through the streets of Paris and recorded historical urban settings in drawings and commentary, including the bridges (Pont Marie, Pont Neuf and others), the Tour St. Jacques, the Place des Victoires, the Louvre, St. Sulpice, the Boulevard Henri IV, the Rue Royale, the Place de la Concorde, and many other spots, including the Hôtel Lambert (Fig. 10). ${ }^{72}$ In his carnet of this trip, Jeanneret quasi draws impressionistically with words, staying away from theorising and instead "bathing" emotionally in the atmosphere of Paris. He also draws atmospheric sketches and often describes the mood of a space rather than simply measuring it or asking for its functional value (Fig. 11). Repeatedly, he refers to either missing greenery or green spaces or to the either architectural or atmospheric value of trees, in particular of their canopies - this very personal experience of Paris sits in contrast to his theoretical investigations of the Bibliothèque Nationale.

In this carnet, Jeanneret often creates links to chapters of "La Construction des villes," refers to the chapters he has already written, complains about the dégagement of Notre Dame, as had been Camillo Sitte's argument, wishes to add to the chapter about enclosing walls (Murs de clôture) ${ }^{73}$ and draws sections through streets as he had done in 1910.

But at the same time as he studies Paris from a historical point of view, Jeanneret judges the city in terms of its modernity. He makes a note to himself, "to devote a chapter in my book to modern Paris, to what has already been achieved." ${ }^{\prime 4}$ And the verdict is not very flattering. Viewing the city from Sacré-Cœur, he finds it lacks structure and order, asking:

Is Paris beautiful? This has not been proven. What is clear: the Pantheon admirably made (sphere); and Notre-Dame, cubes; Invalides, gracious volumes. In such a vast expanse, spires count for — and are worth — nothing. But from Sacré-Cœur one cannot see a single tree .. . The great lines are missing, the great volumes, and order. It is fundamentally random. ${ }^{75}$ 

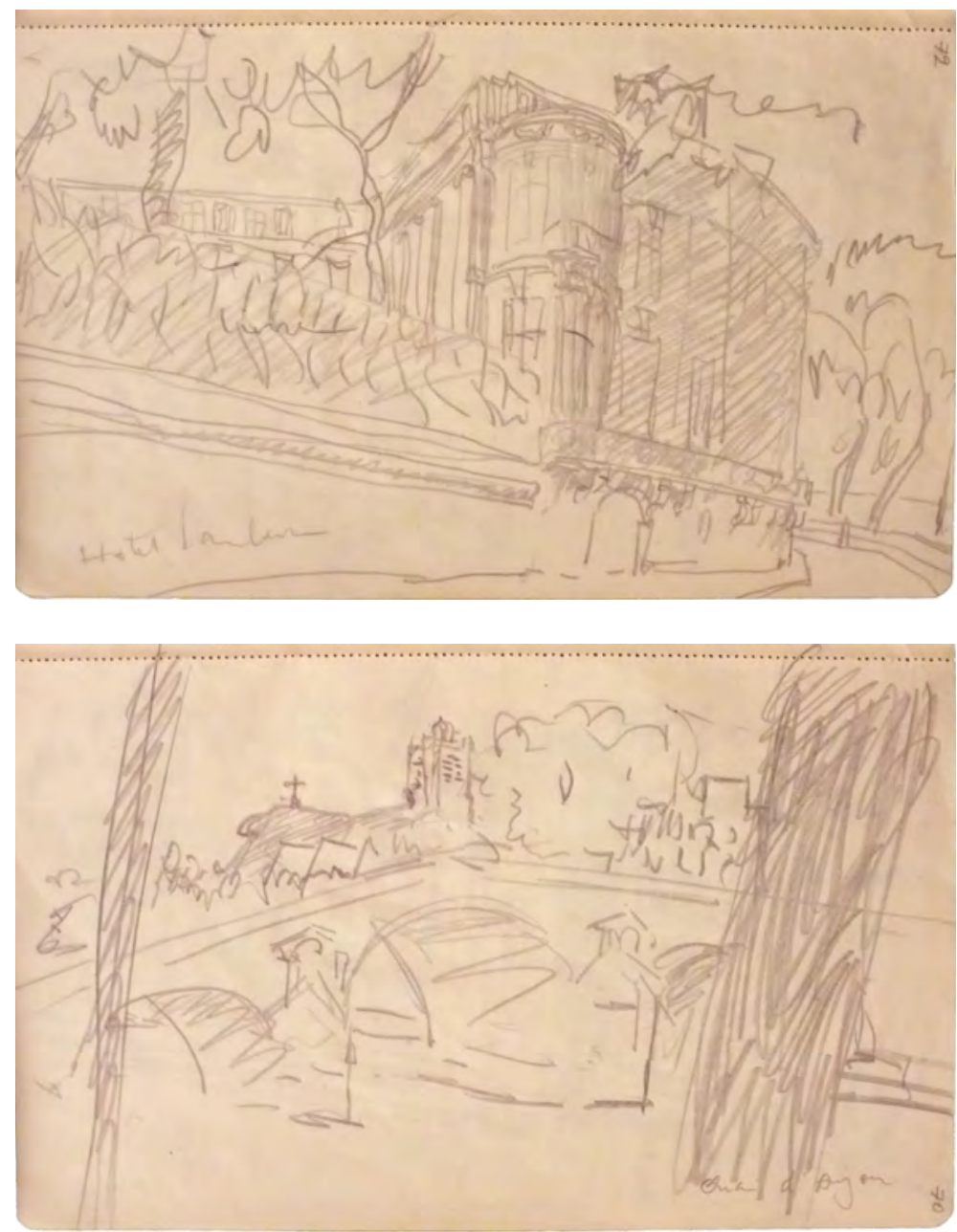

10. Le Corbusier.

Sketch of the Hôtel Lambert, Paris.

Carnet 1915, 72.

11. Le Corbusier.

Sketch of the Quai d'Anjou, Paris.

Carnet 1915, 70. 


\section{Ideas, Inventions Pointing Towards Modernism}

Additionally, it appears that Jeanneret uses the built history of Paris to produce images of the future. He exclaims: "It is a fact that the Tour St. Jacques is the most futuristic, the most cubist architecture one could imagine." 76 While Jeanneret transforms historical architecture in his mind into the future city, he is aided in this process by Auguste Perret. Together with Charles L'Eplattenier and William Ritter, Perret played a vital role for Jeanneret's intellectual development. Jeanneret's notes of early August 1915 in Paris are filled with suggestions Perret seems to have made - apparently he found San Marco in Venice "une infecte camelote, le comble du mauvais goût." "77 He also advised Jeanneret about roads and buildings - and it appears as if Perret was pointing Jeanneret into his future, towards what would become the Ville contemporaine:

Auguste Perret sees towers. Instead of 4,000 square metres of 5-storey buildings, have $1,000 \mathrm{~m}^{2}$ of 20 -storey buildings. And make the $3,000 \mathrm{~m}^{2}$ into parkland with big trees. Align your towers in this sea of greenery. You will have one of the most majestic avenues that a mind can dream up. 9 August $1915 .^{78}$

Further, Perret advised on roads of which he saw two kinds:

Aug. Perret sees two types of street. Preserved $=$ rue de Rivoli. Free, with recesses in height and depth (system developed from 25bis [Rue] Franklin) with at the time 2 or 4 rows of trees at the bottom, in the setbacks, and vegetation in both depth and height. Irrigation and drainage would have to be combined so the concierge could water it all automatically. 10 August $1915 .^{79}$

Through these notes, both from his library studies as well as from walking through Paris and his conversations with Perret, the reader slowly sees elements emerge that point towards the Ville contemporaine and the Plan Voisin: freestanding "cubistic, futuristic" towers, big lines and order brought into 
the city. But we are not there yet. And it is necessary to bear in mind that in all these forward-looking explorations, the picturesque and emotional, atmospheric city is not thrown out. Jeanneret notes:

Do a chapter on the picturesque in which I dot around according to my sketches, photos etc.. Thus I am asking the reader: Do you not have near your home some hill, some watercourse, etc. from which the view is exquisite and where a road will pass? Will this road be well made or ugly? Will it be like Istanbul: the vertiginous drops and the sea, the mosque terraces and the sea, etc.? Like Tirnovo ${ }^{80}$ and each room in each house? Like Le Landeron, and each space [?] on our route, etc., etc., like La Chaux-de-Fonds, from our garden: landscape served up on a plate. No, in fact it is all rubbish, nobody thought of it. $^{81}$

And through these notes and his carnet, together with other evidence from these days such as letters, it becomes visible to what extent Jeanneret was beginning to rethink his attitude towards urban planning.

\section{A Shift in Attitude Towards the Gity}

It is nearly impossible to know what Jeanneret thought of his own work on "La Construction des villes" after his 1915 visit to Paris, because he did not add to or amend it any more. Already before this journey he had known his manuscript would need substantial work in order to be published. But it seems that after his visit, he realized that his 1910 writing could not easily be adapted for a French market - and that, were he to re-write it, he would need to write a completely new piece instead. "La Construction des villes" had become out-dated, through the war and the animosities between Germans and French in general, and particularly so with Jeanneret's own growing nationalism. But also, the field had changed for him. From favouring picturesque solutions, he had grown more attached to the sense of unity 
and grandeur which classicism provided. Both Brinckmann and Laugier had been pivotal in opening up new visions of the urban form. All this was added to by Jeanneret's experience of the Voyage d'Orient and by Perret's suggestions for a future city.

Jeanneret's understanding of what was needed for a city to function as an organic whole had shifted. Would this have had to do with the changing face of the new discipline of urban design, as well? Hinting at the difference between the German notion of Städtebau and the French urbanisme, Dumont has suggested that this was more than a linguistic difference:

A change of attitude and cultural refocusing which were to be translated splendidly by a neologism that appeared in precisely the same period: the word urbanisme. For the invention of a term to denote this new discipline, or rather this bundle of disciplines, did not happen overnight. Depending whether you were an architect or an engineer, looking to Britain or Germany, you would speak of the science of town plans (town planning), or of city building (Städtebau), of urban hygiene or designs . . . ${ }^{82}$

This rings true to a certain extent, however one will need to acknowledge that Sitte's conscious turn towards a Künstlerischer Städtebau had only happened because the German experts on town-planning of the 1880s, such as Josef Stübben, had been perfectly scientific in their approach, and had simply left any artistic considerations behind.

All in all, it is visible that "La Construction des villes" of the years 1910/11 marked a certain attitude and approach towards the city, a well-tempered combination of aesthetic and functional considerations together with a conservative approach to urban spaces. Nothing was wrong with this. But Jeanneret would have begun to sense that there was a bigger, brighter future in urban design to be explored. What this essay then has attempted to show is how Jeanneret extended his view by making use of the combination of historical research (both in reading and writing as in observations of the built reality) with investigations into contemporary developments. 
Passanti quotes a letter of 16 January 1911 to L'Eplattenier in which Jeanneret declares himself freed from the "medievalizing morass . .." and exclaims: "So, all my enthusiasm goes now to Greece and Italy . . ." For Passanti, the shift happened in June 1910. While it is undeniable that Jeanneret began to strongly appreciate the classicist monumental language of urban design as a design tool, it is important to me to underline that throughout "La Construction des villes" - and throughout Le Corbusier's work, in fact - ambivalences remain, one might even say, are being used as an artistic device. Le Corbusier nourishes an affection for ideas or architectural elements that contradict one another, and are strongest when this contradiction is unresolved. Taken in this sense, it seems futile to attempt to locate a precise moment of a switch of mind: the tension between the picturesque and the monumental is introduced at the very moment when Jeanneret delves into the study of Sitte's writings: in April 1910. The point I have made before and will maintain here is that it is quite obvious (when reading his publications, personal notes and letters over a longer period of time) that he is able, like hardly anybody else, to maintain contradictory opinions and beliefs and offer them at the same time. This is also what happens with the question of picturesque vs. monumental which does not get decided in the years of $1910 / 11$, in fact which seems to never fully get decided.

\section{Notes}

1 Stanislaus von Moos, Elemente einer Synthese (Frauenfeld und Stuttgart: Huber, 1968), 337-341.

2 Colin Rowe and Fred Koetter, Collage City (Cambridge, Mass.: MIT Press, 1978), 34.

3 This essay, combining existing and new material, is able to provide additional interpretation. I am grateful for access to private archival material from Switzerland. I thank Kim Sanderson for her translations. 


\section{Christoph Schnoor}

4 For a full account of Le Corbusier's architectural formation, see Harold Allen Brooks, Le Corbusier's Formative Years (Chicago and London: Chicago University Press, 1997).

5 See Antonio Brucculeri, "The Challenge of the "Grand Siècle," in von Moos and Arthur Rüegg, eds., Le Corbusier before Le Corbusier (New Haven and London: Yale University Press, 2002), 99-108.

6 Brooks, Formative Years, 207.

7 Christoph Schnoor, ed., La Construction des villes: Le Corbusiers erstes städtebauliches Traktat von 1910/11 (Zurich: gta, 2008).

8 Francesco Passanti, "Architecture: Classicism, Proportion and Other Issues," in Le Corbusier before Le Corbusier, 82.

9 See Ibid., 81-83.

10 Camillo Sitte, Der Städte-Bau nach seinen künstlerischen Grundsätzen (Vienna: Teubner, 1889).

11 Charles L'Eplattenier, "L'esthétique des villes", in [Résumé de l'intervention de Charles L'Eplattenier à l'] Assemblée générale des délégués de l'Union des villes suisses réunis à la Chaux-de-Fonds à l'Hôtel de Ville, les 24 et 25 septembre 1910, Compte-rendu des délibérations de l'assemblée générale des délégués de l'union des villes suisses, 1910; Beilage zum schweizerischen Zentralblatt für Staats- und GemeindeVerwaltung 11 (1910), 24-31.

12 Camillo Sitte's Der Städte-Bau nach seinen künstlerischen Grundsätzen has been translated into English as: Camillo Sitte, City Planning According to Artistic Principles, trans. George R. Collins and Christiane Crasemann Collins (London: Phaidon Press, 1965). In addition to Sitte, these are: Karl Henrici, Beiträge zur praktischen Ästhetik im Städtebau (Munich: Callwey, 1904); Paul Schultze-Naumburg, Der Städtebau. Kulturarbeiten, Vol. 4 (Munich: Callwey, 1906); Johann Hubatschek, Die bautechnischen Aufgaben einer modernen Stadt (Linz: Mareis, 1905); Theodor Fischer, Stadterweiterungsfragen (Stuttgart: DVA, 1903).

13 Albert Erich Brinckmann, Platz und Monument (Berlin: Wasmuth, 1908).

14 "Eine besondere Leistung Brinckmanns ist die Neubewertung der städtebaulichen Leistungen von Renaissance, Barock und Klassizismus." Jochen Meyer, Afterword to Platz und Monument (Reprint of 1st ed. 1908, Berlin: Gebr. Mann, 2000), 187.

15 Meyer, Afterword to Platz und Monument, 178.

16 Manuscript Lcdv 182-188, in Schnoor, La Construction des villes, 369-373.

17 "Es wird nichts damit erreicht, daß man in eine Stadt etwas hineinstellt oder irgend etwas in ihr aufbaut, alles kommt auf das Wie an. Aus den verschiedenen Teilschönheiten resultiert dann die 


\section{Urban History and New Diregtions}

Gesamtschönheit der Stadt, aus den wohldurchgebildeten harmonischen Einzelheiten soll eine große und reiche Mannigfaltigkeit der Gesamterscheinung entwickelt werden.” Brinckmann, Platz und Monument, 140.

18 See Sitte's project for the transformation of the Votive Church plaza in Vienna, in the chapter: "Example of an Urban Arrangement", 141-159 of Sitte, City Planning According to Artistic Principles.

19 Walter G. Behrendt, Die einheitliche Blockfront als Raumelement im Stadtbau (Berlin: Cassirer, 1911).

20 "Das Haus bestimmt die Physiognomie der Straße, der Stadt, es ist das Material der Stadtbaukunst." Brinckmann, Platz und Monument, 170.

21 "Or 1 maison 1 ville, une chambre, tout ça c'est que l'application du goût du beau volume. C'est ce volume qu'il faut apprendre à comprendre aux foules, à savoir créer, aux architectes. Ils feront la chambre, alors et puis la maison; et puis la rue, et puis la place, en juste volume, en beau volume. Et concluons par ce que M. Brinckmann résume parfaitement son livre. Construire des villes veut dire: av. du matériel de maison dresser des volumes! (Städte bauen heißt: mit dem Hausmaterial Raum gestalten!)” Manuscript Lcdv 448-449, in Schnoor, La Construction des villes, 558.

22 "Pourquoi tant des places anciennes, restées à l'abri des dévastations cadastriques, offrent-elles dans leur surface de bizarres ondulations? Ce sont des rigoles qu'ont creusées petit à petit les voitures en repassant dans la même piste, déterminant des aires légèrement exhaussées qui devinrent les socles tout désignés pour l'emplacement des monuments. C'est en ces points précis qu'il faut chercher les antiques fontaines, les puits, les oratoires, le grand arbre et son banc de pierre, rendez-vous tranquille du soir. Sitte dit avoir observé, que d'instinct, en hiver, les gamins dans les villages plantent leurs hommes de neige toujours au 'point mort."' Manuscript Lcdv 176-178, in Schnoor, La Construction des villes, 366-367.

23 Schnoor, La Construction des villes, 129.

24 These are illustrations 34, page 103, and 40, page 119 (Figs. B2-20-329 and -335, FLC).

25 Brooks believed this drawing by Jeanneret to date from 1915, not, as it does, from 1910.

26 "Eine Straße wird nicht dadurch schön, daß man Miethausfassaden wie ein Kartenblatt biegt." Brinckmann, Platz und Monument, 168.

27 "Das Verlangen nach Befreiung des Blickes ließ die gerade reinliche Straße entstehen. Hat die gewundene, unregelmäßige Straße . . . auf hügligem Gelände . . . als Kontrast zur geraden freien Straße durchaus ihre ästhetische Berechtigung, eine vollendet monumentale Situation kann sie nicht schaffen." Brinckmann, Platz und Monument, 168. 


\section{Christoph Schnoor}

28 "La ligne noble par excellence, dans la nature. Mais le plus rare aussi c'est la droite." Manuscript Lcdv 123, in Schnoor, La Construction des villes, 327.

29 "Telle est l'avenue des Champs-Elysées à Paris couronnée par l'immense arc de triomphe derrière lequel se couche en gloire le soleil. Tel à Berlin, le soir, 'l'effet' de la Siegesallee à l'extrémité de laquelle se dresse la Siegessäule toute noyée dans le pourpre du couchant et se mirant presque dans le macadam poli par les automobiles. - La Bismarckstrasse à Charlottenburg aux dimensions énormes qui suit une direction inflexible pendant d'interminables kilomètres, seule droite, à peu près, au travers de quartiers qui sont et seront tous tracés suivant les procédés nouveaux." Manuscript Lcdv 123-24, in Schnoor, La Construction des villes, 327-328.

30 "En effet, des disciples maladroits de C. Sitte, outrepassant ses théories en seraient arrivés presque, si on n'y mettait le holà, à revivre l'époque médiévale si brillamment réhabilitée par le livre de l'éclectique Viennois. Ces réactionnaires, - Monsieur Brinckmann entre autres dans sa très belle étude 'Platz und Monument' - sont placés quelque peu dans une situation analogue à celle de Sitte, voici 30 ans.” Manuscript Lcdv 37, in Schnoor, La Construction des villes, 255.

31 "Jouissant des réformes accomplies, mais redoutant déjà une trop prompte satisfaction, et, par ce, l'engendrement d'un statu quo fatal, ils devinent certaines tendances morbides; mais en les dénonçant, - comme le fait M. Brin[c]kmann, - sans considérations accessoires, ils risquent de troubler le lecteur non averti, simple spectateur distrait n'ayant pas connaissance du fond de la question.” Manuscript Lcdv 37, in Schnoor, La Construction des villes, 255.

32 Brinckmann, Platz und Monument, 140. Manuscript Lcdv 436, in Schnoor, La Construction des villes, 549.

33 Le Corbusier, Urbanisme (Paris: Flammarion, 1994, originally Paris: Crès, 1925), 65. "We have now formulated an ideal and precise aim. Already, in the time of Louis XIV, the Abbé Laugier had propounded the following axioms: 1. Chaos, disorder and a wild variety in the general lay-out (i.e. a composition rich in contrapuntal elements like a fugue or symphony). 2. Uniformity in detail (i.e. reticence, decency, 'alignment' in detail)." Le Corbusier, The City of To-Morrow, trans. Frederick Etchells (New York: Payson and Clarke, 1929), 72.

34 This is the last of the thirteen cahiers that make up the 1910/11 version of "La Construction des villes." Manuscript Lcdv 475-520, in Schnoor, La Construction des villes, 566-594.

35 "Berlin ne me conquiert pas et dès que l'on sort des immenses avenues, c'est de l'écœurement, de l'horreur." Charles-Edouard Jeanneret, letter to his parents, 21 October 1910, R1-5-68 FLC.

36 Manuscript Lcdv 495, 520, in Schnoor, La Construction des villes, 579, 594.

37 Hendrik Petrus Berlage, Grundlagen und Entwicklung der Architektur. Vier Vorträge (Berlin: Bard, 1908). 


\section{Urban History and New Diregtions}

38 August Thiersch, Die Proportionen in der Architektur (Darmstadt: Bergsträsser, 1893); also in Die architektonische Composition. Handbuch der Architektur, Part 4, Vol. 1 (Darmstadt: Diehl, 1883).

39 See Passanti, "Architecture: Proportion, Classicism and Other Issues," 78-79.

40 Manuscript Lcdv 489, in Schnoor, La Construction des villes, 576.

41 “. . . This, however, is not sufficient: it needs a Le Nôtre to design the plan for it, someone who applies taste and intelligence so that there is at one and the same time order and fantasy, symmetry and variety, with roads here in the pattern of a star, there in that of a patte d'oie, with a featherlike arrangement in one place, featherlike in another, with parallel roads further away and everywhere carrefours of different designs and shape." Laugier, An Essay on Architecture, trans. Anni and Wolfgang Herrmann (Los Angeles: Hennessey \& Ingalls, 1977), 128.

42 Laugier, Essay on Architecture, 128.

43 Manuscript LCdv 516-19, in Schnoor, La Construction des villes, 593-594.

44 Von Moos and Rüegg, Le Corbusier before Le Corbusier, Catalogue entries 8-14, 170-195.

45 Schnoor, "Soyez de votre temps' - William Ritter et Le Corbusier," in Le Corbusier. La Suisse, Les Suisses, XIII Rencontre de la Fondation Le Corbusier (Paris: Fondation Le Corbusier, Éditions de la Villette, 2006), 104-127.

46 "Faites pour vous les belles choses qu'il vous plaira, faites pour votre peuple les belles choses qu'il lui faut, et ce n'est pas vous, mais lui le juge de ce qu'il lui faut." Ritter to Jeanneret, 26 September 1911 (SLA Bern, 1911.291).

47 'Criez au paradoxe, mais réfléchissez deux minutes. C'est l'estomac qui digère et la nourriture qui est faite pour l'estomac: représentez vous la révolte de la nourriture contre l'estomac: les aliments ont décidé un beau matin qu'avant tout il faut être beau. La dessus l'estomac ne les supporte plus et réponds je me f. de votre beauté, la beauté pour moi c'est que je vais digérer. Le problème n'est pas d'être beau théoriquement mais digestiblement." Ibid.

48 'Si l'on jette des perles aux cochons, c'est pas le cochon qui est bête, et je m'étonne que personne ne semble s'en être avisé. Au revoir. L'idéal des porcs est d'être un très joli goret: c'est votre devoir de l'y aider et non de les changer en gazelles ou en pintades. Regardez l'acropole elle vous dira si je divague ou non et si je suis un vieux c. [on]." Ibid.

49 Francesco Passanti has written extensively about this question.

50 See Schnoor, La Construction des villes, 220-223.

51 Gordon Cullen, Townscape (London: Architectural Press, 1961); Kevin Lynch, The Image of the City (Cambridge, Mass.: MIT Press, 1960). 


\section{Christoph Schnoor}

52 These visits are still not fully researched, despite Philippe Duboy's study of the library visit in Paris. With hundreds of fiches/tiny filled pages with notes still not fully transcribed, there is further research to be done.

53 Brooks, Formative Years, 368.

54 Schnoor, La Construction des villes, 165-169.

55 Jeanneret, Carnet 1914. Private Archive, Switzerland.

56 "ce que fait la forme de la carrière ce sont les petites maisons." Jeanneret, Carnet 1914, n.p. [4-5]. Private Archive, Switzerland.

57 Jeanneret, Carnet 1914, n.p. [9]. Private Archive, Switzerland.

58 For the itinerary see Brooks, Formative Years, 369-372.

59 Jeanneret, Carnet 1914, n.p. [52]. Private Archive, Switzerland.

60 "Je pense venir bientôt à Paris, pour la publication d'un bouquin que j'avais écrit sur la Construction des villes, plans d'extension, etc. Un gros travail très avancé, mais écrit dans [un] esprit étroit et tortueux. Je le remanierai complètement. Je viendrai à Paris pour trouver un éditeur, me disant que l'heure est peut-être favorable de sortir cette étude de son tiroir; et que ce modeste effort pourrait être utile, en ce moment où l'on discute de lois relatives à ce thème." Jeanneret to Auguste Perret, 30 June, 1915. Marie-Jeanne Dumont, Le Corbusier. Lettres à Auguste Perret (Paris: Éditions du Linteau, 2002), 145ff.

61 Here, Jeanneret refers to a letter exchanged with William Ritter in 1911; see above.

62 Jeanneret, unpublished pages of the manuscript "La Construction des villes."

63 "Es ist das Verhängnis der Architektur des XIX. Jahrhunderts, daß den Architekten das Gefühl für Raum und Raumwirkung versagte . . . Gelingt es auch, im Detail historisch genau zu kopieren, so fehlt die Erkenntnis, daß die wechselnde architektonische Form nur Ausdruck eines sich wandelnden Raumgefühles ist.” Brinckmann, Platz und Monument, 153.

64 Manuscript Lcdv 434, in Schnoor, La Construction des villes, 547.

65 Brooks, Formative Tears, 403.

66 Pierre Patte, Monumens érigés en France à la gloire de Louis XV (Paris, 1765); Gabrielle Pérelle, Topographie de France, Paris: Jombert 1753. See Brucculeri, "The Challenge of the 'Grand Siècle,"' and the catalogue entry 'Parisian Urbanism,' in von Moos and Rüegg, Le Corbusier before Le Corbusier, 200.

67 The bibliography, sketches and excerpts are filed under B2-20 at the Fondation Le Corbusier.

68 Philippe Duboy transcribed and published some of Jeanneret's notes in "Charles-Edouard 


\section{Urban History and New Diregtions}

Jeanneret à la Bibliothèque Nationale," Architecture, Mouvement, Continuité 49 (1979), 9-12, and Casabella 531/532 (1987), under the heading 'L.C.B.N. 1915.'

69 Where listed in the 1910 bibliography, these appear as: Albert Erich Brinckmann, Spätmittelalterliche Stadtanlagen in Sïdfrankreich (Berlin: Schenck 1910); Charles Buls, L'Esthétique des villes (Bruxelles: Bruyland-Christope, 1893); Roland Fréart, Sieur de Chambray, Parallèle de l'architecture antique av. la moderne (Paris: Martin 1650); Laugier's Essay (1753) and Observations (1765); Pierre Patte, Mémoire sur les objets les plus importans de l'architecture (Paris: Rozet, 1769); Joseph Stübben, Der Städtebau. Handbuch der Architektur, Part 4, Vol. 9 (Darmstadt: Bergstrasser, 1890); and Raymond Unwin, Grundlagen des Städtebaues (Berlin: Baumgärtel, 1910), originally published as TownPlanning in Practice (London: Fisher and Unwin, 1909). This bibliography follows Jeanneret's notes in B2-20 FLC.

70 "Le Corbusier, à l'évidence, connaissait mieux l'architecture et les revues allemandes que ce qui touchait à la France." Marie-Jeanne Dumont, ed., Le Corbusier, Lettres à ses maîtres, vol. 1, Lettres à Auguste Perret (Paris: Éditions du Linteau, 2002), 143n2.

71 See Francesco Passanti, “The Vernacular, Modernism and Le Corbusier," JSAH 56 (1997), 438-451.

72 These experiences are recorded in a separate carnet (filled with comments and drawings on architecture and the city on almost 150 pages), kept in a private archive in Switzerland.

73 Jeanneret, Carnet 1915, 75.

74 "Consacrer ds mon livre un chapitre au Paris moderne, aux choses déjà réalisés." Jeanneret, Carnet 1915, 21.

75 "Est-ce beau Paris ? C'est pas prouvé. D'évident, ceci : le Panthéon fait admirablement, (boule) et N-Dame, cubes, Invalides, volumes gracieux. Dans une si grande étendue, les flèches ne comptent et ne valent rien . . . Mais du Sacré-Cœur, on ne voit aucune arbre . . . Il manque des grandes lignes, des grands volumes, une ordonnance. C'est un hasard, au fond.” Jeanneret, Carnet 1915, 22.

76 "Il est un fait que la tour St Jacques es la plus futuristique la plus cubistique architecture qu'on puisse imaginer.” Jeanneret, Carnet 1915, 23.

77 B2-20-108 FLC.

78 "Auguste Perret voit des tours. Au lieu de 4000 mètres carrés de maisons à 5 étages, prenez $1000 \mathrm{~m}^{2}$ de maisons à 20 étages. Et les $3000 \mathrm{~m}^{2}$ faites en du parc à grds arbres. Alignez vos tours dans cette mer de verdure. Vous aurez l'une de plus majestueuses allées que cerveau puisse rêver. 


\section{Christoph Schnoor}

9 août 1915." B2-20-106 FLC.

79 "Aug. Perret voit 2 types de rues. Préservé = rue de Rivoli. Libre, avec redans en hauteur v. profondeur (système développé de 25bis [Rue] Franklin) avec alors 2 ou 4 allées d'arbre en bas, dans les redans, et vegetation en profondeur et en hauteur. Il faut alors combiner des irrigations et drainages pour arrosage automatique du tout par le concierge. 10 août 1915." B2-20-107 FLC.

80 i.e. Veliko Tarnovo, Bulgaria.

81 "Faire un chapitre sur le pittoresque ou je saute du coq à l'âne d'après mes croquis, photos etc. Ainsi je pose la question au lecteur : N'avez vous pas proche de par vous n'importe quelle colline, n'importe quel cours d'eau etc. d'où la vue est exquise et où une rue va passer ? Passera-t-elle bien ou laide? Aussi Stamboul : les dégringolades et la mer, les terrasses des mosquées et la mer, etc. Ainsi Tirnovo et chaque sale [?] de chaque maison. Ainsi Landeron, et chaque chambre sur le cours, etc. etc. Ainsi la Chaux-de-Fonds, depuis notre jardin : assiette au paysage. Mais non, tout est foutu, personne n'y a pensé." B2-20-116 FLC.

82 Dumont, Lettres à Auguste Perret, 147-148.

83 Passanti, "Architecture: Classicism, Proportion and Other Issues", 82-83. 